\title{
Maternal Nutrition and the Child's Sex: A Review
}

\author{
Mahdieh Pouryazdanpanah Kermani ${ }^{\mathbb{D}}$, Mohsen Nematy $\mathbf{2}^{2^{\star \mathbb{D}}}$
}

\begin{abstract}
Objectives: Over the last years, maternal nutrition and its effect on the fetal health have been much focused on and different aspects of it have been widely investigated. However, the impact of diet on the child sex has not been well understood; it has been considered by the parents from past until now. According to hypotheses indicating that maternal nutrition status was associated with the child gender, this study was conducted to find out whether maternal nutrition would affect the child's sex in humans.

Materials and Methods: A systematic literature search in English was performed with pre-determined keywords on preconception maternal diet, maternal nutritional status, fetal sex, and sex ratio in international electronic databases (i.e., ISI Web of Knowledge, PubMed, Cochrane Library, and Scopus) with no time limitation. Reviews, letters to the editors, commentaries, editorials, experts' opinions, and publications without available electronic full texts were excluded.

Results: Fifteen studies fulfilled the criteria and were categorized into 2 groups; the first group included publications on maternal nutritional status. Despite the heterogeneity of the articles, it was assumed that the nutritional status did not affect the sex ratio at birth except for malnutrition. In the second group which included publications on the maternal diet, results illustrated a relation between a diet with high sodium and potassium intake and male gender. Besides, high magnesium and calcium intake were found to be related to female foetus.

Conclusions: Based on the results obtained, it can be concluded that there are not enough publications regarding the effect of maternal nutrition on the sex of child in the literature. Accordingly, more researches are warranted.

Keywords: Sex selection, Maternal nutrition, Nutritional status
\end{abstract}

\section{Introduction}

Nowadays, the influence of maternal nutrition on different aspects of labour and fetal health is widely investigated. Optimal life style and proper diet are recommended to decline the risk of birth defects (1). Dietary advices should be offered to women for promoting their child health and weight (2). It is believed that restricted nutrition could interfere with physiologic adjustments of pregnancy, cause fetal developmental impairment, induce labour, and increase the risk of gestational diabetes mellitus $(3,4)$. In addition, the ability to have an effect on offspring sex is an issue that is often considered by the parents from past until now. A number of reasons have been mentioned for sex selection including family planning, cultural background, parental preference of a specific gender, and prevention of the sex-linked genetic diseases. Natural and technical methods such as diet, timing of sexual intercourse, prefertilisation sperm sorting, and pre-implantation genetic diagnosis (PGD) are available for sex selection. Except for sex selection for medical indication that must be done by PGD with $100 \%$ accuracy, cost, ethics, and society believes propel the parents to use nutrition (5).

According to some hypotheses, healthy and nourished mothers mostly give birth to the boys; meanwhile, the sex ratio at birth is found to be affected by maternal socioeconomic conditions including the nutritional status $(6,7)$.

This study aimed to evaluate the publications on the relationship between maternal nutrition and sex of the offspring in humans.

\section{Materials and Methods \\ Data Sources}

A systematic literature search was performed across international electronic databases (e.g., ISI Web of Knowledge, PubMed, Cochrane Library, and Scopus) with no time limitation using pre-determined keywords. The English search strategy is shown in Table 1.

\section{Study Selection}

Selected publications included original articles in English with different methods and population sizes regarding preconception maternal diet, nutritional status, fetal sex, or sex ratio in humans. In addition, a number of data were excluded from the study including reviews, letters to the editors, commentaries, editorials, experts' opinions, and publications without available electronic full texts.

After initial search using search terms strategy, the related publications were selected focusing on the title/ abstract review. Following excluding duplicate articles, full

Received 23 October 2016, Accepted 1 January 2017, Available online 2 February 2017

${ }^{1}$ Department of Nutrition, School of Health, Kerman University of Medical Sciences (KUMS), Kerman, Iran. ${ }^{2}$ Department of Nutrition, School of Medicine, Mashhad University of Medical Sciences (MUMS), Mashhad, Iran.

*Corresponding Author: Mohsen Nematy, Fax: +98(51) 38002421 \& 38002422, Tel: +98 9153218 798, Email: NematyM@mums.ac.ir 
Table 1. Search Terms and Search Strategy

\begin{tabular}{ll}
\hline$\#$ & Search Term: Sex Selection \\
\hline 1 & Sex \\
2 & Gender \\
3 & Preconception \\
4 & Pre-Conceptional \\
5 & Selection \\
6 & Pre-Selection \\
8 & Offspring Sex \\
9 & Offspring Gender \\
10 & Sex Ratio \\
11 & Son \\
12 & Boy \\
13 & Daughter \\
14 & Girl \\
15 & \#01 OR \#02 OR \# 03 OR \#04 \\
16 & \#05 OR \#06 \\
17 & \#15 AND \#16 \\
18 & \#8 OR \#9 OR \#10 OR\# 11 OR \#12 OR \#13 OR \#14 OR \#17 \\
$\#$ & Search Term: Nutritional Status \\
19 & Nutrition \\
20 & Nutritional \\
21 & Nutritional Status \\
22 & Under Nutrition \\
\hline
\end{tabular}

texts of the selected articles were evaluated for inclusion/ exclusion criteria.

\section{Results}

A total of 695 articles were obtained in the initial search out of which 641 were excluded as they were not relevant to the review or were duplicates. After evaluating the full texts for inclusion/exclusion criteria, 15 articles were selected to be included in this study.

Despite the heterogeneity of the articles in terms of subjects and methodology, they could be categorized into 2 groups according to the concepts reported; the first group consisted of publications which mentioned the maternal nutritional status (including anthropometric measurements, availability of food by caloric supply, and famine exposure) and the second group included publications on the maternal diet. Tables 2 and 3 show a brief summary of the studies in maternal nutrition and maternal diet groups included in the review.

\section{Maternal Nutritional Status}

Song studied 220280 Chinese children born between 1956 and 1965, a period that included one of the largest famine during 1959-1961. The famine exposure index (i.e., the ratio between the expected and observed size of the famine cohort data) was calculated. Besides, its relation with the male birth size was investigated through conducting the "difference-in-differences" (DID) analysis for covering the cohort difference and regional, or urbanrural differences for each year; a significant sex ratio decrease was found in years 1958, 1961, and also 1964 in the urban population $\left(\mathrm{DID}_{1958}=-0.049,95 \% \mathrm{CI}[-0.095\right.$, $-0.002], \mathrm{DID}_{1961}=-0.089,95 \%$ CI $[-0.142,-0.031]$, $\mathrm{DID}_{1964}=-0.061,95 \%$ CI $\left.[-0.106,-0.011]\right)$. However, despite the severity of the famine induced malnutrition in the rural region, no significant decrease was observed in the rural population $\left(\mathrm{DID}_{1958}=-0.012,95 \% \mathrm{CI}[-0.035\right.$, $0.012], \mathrm{DID}_{1961}=-0.016,95 \% \mathrm{CI}[-0.043,0.013], \mathrm{DID}_{1964}=$ $0.003,95 \% \mathrm{CI}[-0.020,0.026])$, It means that rural mothers missed much more fetuses than urban ones because of their low nutritional status. The decline of sex ratio in 1964 showed long-term effect of famine which was greater in rural mothers as there were more severe depletion of their supply without any restoration (8).

Song also examined the effect of malnutrition on sex ratio in a retrospective study of 830045 live-born Chinese children during the period of 1929 to 1989 using a logistic regression model. The results indicated that mothers in poor conditions were more likely to give birth to the girls. He suggested a V-shaped curve for the pattern of famine effect on the male birth. The first decline in the proportion of the male birth occurred 6 months after the famine, indicating the cumulative effect of malnutrition. The compensatory increase occurred 1 year after the end of the famine, indicating that it took some time for rebounding of mother's supply to reach normal sex ratio at birth (9).

Using the data obtained from Dutch Hunger Winter of 1944-1945, Cramer and Lumey tested the relationship between maternal nutritional status and sex ratio at birth. After studying monthly births at 5 time points of war and famine (i.e., the prewar period, the war period without famine, the war period with famine, the early postwar period, and the later postwar period), they concluded that sex ratio was almost constant $\left(\chi^{2}=0.64, \mathrm{df}=4\right)(10)$.

Similarly, Denny analyzed the data of 8249 new born children in a survey in the United Kingdom and evaluated the relationship between the sex of children and their parents' body mass index (BMI). No significant relationship was found $\left(\mathrm{R}^{2}=0.000, P=0.99\right)$ between the male children and maternal BMI (11).

The study on the variations of the sex ratio at birth in Germany during 1787-1802 and also the years of the French Revolutionary Wars, with dietary changes and food availability decline (12) demonstrated a significant decline in the war and post war sex ratio at birth $(0.502$ and 0.469 , respectively) in accordance with a prewar sex ratio of $0.566(P<0.05)(13)$.

In the same vein, another study was conducted on the Dutch famine in 1944-1945. In this study, the sex ratio was considered in 3 trimesters of pregnancy in 4050 births. Only those women who spent their first trimester in famine delivered more male children (odds ratio (OR) $=1.31,95 \%$ CI $1.09-1.48, P=0.004)$ and the sex ratio among others was similar to the years of 1943 and 1947, that is, the years without war and famine (first trimester: 
$\mathrm{OR}=1.05,95 \% \mathrm{CI}[0.86-1.29]$, second trimester: $\mathrm{OR}=1.01$, 95\% CI [0.92-1.10], and third trimester: $\mathrm{OR}=1.03,95 \%$ CI [0.97-1.10]) (14).

To trace the relationship between maternal nutritional status and offspring's sex, 3 other studies with similar protocols were carried out in Ethiopia in 2000 as a year with an acute food shortage which necessitated emergency food aid (15).

Moreover, Stein et al analyzed the data of 7223 women with at least one birth in the previous 5 years, retrospectively. A very weak $\left(\mathrm{R}^{2}=0.0057\right)$ non-significant inverse relationship was found between the percentage of recent male birth and BMI of less than $18.5 \mathrm{~kg} / \mathrm{m}^{2}$ as a current maternal nutritional status marker adjusted for other determinants of maternal nutritional status (OR=0.94, 95\% CI [0.84-1.04], $P>0.05$ ) (16).

Gibson and Mace also studied 324 married women below 50 years of age from a birth-history calendar in southern Ethiopia in 2000. The mid-upper arm muscle area and the offspring sex were significantly correlated $(\beta=0.08$, standard eror $[\mathrm{SE}]=0.02, P=0.0005)$. A similar association was reported between the last child's sex and both the mid-upper arm circumference $(\beta=0.187$, $\mathrm{SE}=0.06, \quad P=0.001)$ and $\mathrm{BMI} \quad(\beta=0.167, \quad \mathrm{SE}=0.06$,
$P=0.005)(17)$.

Similarly, Mace and Eardley analyzed the data of 6417 women with a child in 5 years old or younger. The odds of rural mothers, whose BMI were less than $18.5 \mathrm{~kg} / \mathrm{m}^{2}$, having a girl were about $15 \%$ higher than having a boy $(\beta=1.158, P<0.05)$; however, no significant association was seen in urban mothers in this regard $(\beta=0.851$, $P>0.05)(18)$.

Cagnacci et al studied 10239 Italian children born in 1997-2001 and their mothers' pre-pregnancy weight and weight gain during pregnancy, retrospectively. The sex ratio was significantly lower in women with prepregnancy weight in first quartile than others $(0.497$ versus $0.525 ; P<0.01$ ); besides, their weight gain during pregnancy was lower in the fourth quartile than that of the others $(P<0.054)(19)$.

In the same way, Manning et al measured weight and waist and hip circumference in 102 women. According to a multiple regression model, only waist circumference was significantly correlated with sex ratio $(\beta=0.083, t=2035$, $P=0.023)(20)$.

In addition, Williams and Gloster tested the relationship between the sex ratio and available calorie in different countries. A significant correlation was detected between

Table 2. Characteristics of Included Articles in Maternal Nutritional Status

\begin{tabular}{|c|c|c|c|c|c|}
\hline Author & Year & Country & Objective & Population & $\begin{array}{l}\text { Nutritional Status } \\
\text { Assessment Method }\end{array}$ \\
\hline Song & 2014 & China & $\begin{array}{l}\text { To determine the implication of maternal } \\
\text { nutritional condition on sex ratio at birth }\end{array}$ & $\begin{array}{l}220280 \text { children born between } 1956 \\
\text { and } 1965\end{array}$ & Famine Exposure \\
\hline Song & 2012 & China & $\begin{array}{l}\text { To assess the effect of famine on sex ratio } \\
\text { at birth in long term trend }\end{array}$ & $\begin{array}{l}\text { Data from a survey of } 830045 \text { live- } \\
\text { born children of } 310101 \text { women }\end{array}$ & Famine Exposure \\
\hline $\begin{array}{l}\text { Cramer \& } \\
\text { Lumey }\end{array}$ & 2010 & Holland & $\begin{array}{l}\text { To test an association of sex at birth and } \\
\text { mother's preconception diet. }\end{array}$ & $\begin{array}{l}\text { Data for the Dutch hunger winter of } \\
1944-1945\end{array}$ & $\begin{array}{l}\text { Famine \& War } \\
\text { Exposure }\end{array}$ \\
\hline Denny & 2008 & UK & $\begin{array}{l}\text { To assess the relation between their } \\
\text { parents' BMI and height and sex ratio }\end{array}$ & $\begin{array}{l}\text { Data of } 8249 \text { born child from a survey } \\
\text { in United Kingdom }\end{array}$ & BMI \\
\hline Kemkes & 2006 & Germany & $\begin{array}{l}\text { To test if the sex ratio decrease in } \\
\text { stressful preconception condition }\end{array}$ & $\begin{array}{l}\text { Birth records of 1787-1802 in four } \\
\text { villages }\end{array}$ & War Exposure \\
\hline Stein et al & 2004 & Ethiopia & $\begin{array}{l}\text { To test the relation of the nutritional } \\
\text { status and sex ratio }\end{array}$ & $\begin{array}{l}\text { Data from the Ethiopia demographics } \\
\text { and health survey of women of } \\
\text { reproductive age and their children } \\
\text { under } 5 \text { years of age in } 2000\end{array}$ & BMI \\
\hline Stein et al & 2004 & $\begin{array}{l}\text { The } \\
\text { Netherlands }\end{array}$ & $\begin{array}{l}\text { To test the influence of maternal under } \\
\text { nutrition on sex ratio }\end{array}$ & $\begin{array}{l}\text { Data for births during the Dutch } \\
\text { Hunger Winter of } 1944-194\end{array}$ & Famine Exposure \\
\hline $\begin{array}{l}\text { Mace \& } \\
\text { Eardley, }\end{array}$ & 2004 & Ethiopia & $\begin{array}{l}\text { To assess the relationship between } \\
\text { maternal nutrition and sex ratio at birth. }\end{array}$ & $\begin{array}{l}\text { Data of } 6417 \text { women from large } \\
\text { national survey }\end{array}$ & BMI \& Height \\
\hline Gibson & 2003 & Ethiopia & $\begin{array}{l}\text { To assess the relation between maternal } \\
\text { nutritional status and recent baby sex }\end{array}$ & $\begin{array}{l}\text { Data from } 324 \text { women in } 2000 \text { from an } \\
\text { Oromo community }\end{array}$ & $\begin{array}{l}\text { Mid-upper Arm } \\
\text { Muscle Area \& BMI }\end{array}$ \\
\hline Cagnacci et al & 2004 & Italy & $\begin{array}{l}\text { To evaluate the effect of pre-pregnancy } \\
\text { weight on the sex ratio }\end{array}$ & $\begin{array}{l}\text { Data on } 10239 \text { children born 1997- } \\
2001\end{array}$ & $\begin{array}{l}\text { Pre-pregnancy } \\
\text { Weight }\end{array}$ \\
\hline Manning et al & 1996 & UK & $\begin{array}{l}\text { To test hormonal effect on sex ratio in } \\
\text { human }\end{array}$ & 102 women between $35-55$ years & $\begin{array}{l}\text { Waist \& Hip } \\
\text { Circumference \& } \\
\text { Weight }\end{array}$ \\
\hline $\begin{array}{l}\text { Williams \& } \\
\text { Gloster }\end{array}$ & 1992 & $\begin{array}{l}\text { Different } \\
\text { country }\end{array}$ & $\begin{array}{l}\text { To evaluate the relation between sex } \\
\text { ratio at birth and various country's caloric } \\
\text { supply }\end{array}$ & $\begin{array}{l}\text { Information on the number of live } \\
\text { births from } 1967 \text { to } 1986 \text {. }\end{array}$ & $\begin{array}{l}\text { Caloric Supply Per } \\
\text { capita }\end{array}$ \\
\hline
\end{tabular}


Table 3. Characteristics of Included Articles in Maternal Diet

\begin{tabular}{|c|c|c|c|c|c|}
\hline Author & Year & Country & Objective & Design & Population \\
\hline $\begin{array}{l}\text { Noorlander } \\
\text { et al }\end{array}$ & 2010 & $\begin{array}{l}\text { The } \\
\text { Netherlands }\end{array}$ & $\begin{array}{l}\text { To assess maternal diet low in sodium \& } \\
\text { high in calcium on sex of offspring }\end{array}$ & $\begin{array}{l}\text { Taking low \& sodium high calcium diet before } \\
\text { conception by couples with willing of girl }\end{array}$ & 172 couples \\
\hline $\begin{array}{l}\text { Mathew } \\
\text { et al }\end{array}$ & 2008 & UK & $\begin{array}{l}\text { To test the relation between preconception } \\
\text { maternal diet and the foetus sex }\end{array}$ & $\begin{array}{l}\text { Prospective study of pregnant women's diet } \\
\text { before conception }\end{array}$ & $\begin{array}{l}\text { Date from } 740 \\
\text { British women }\end{array}$ \\
\hline
\end{tabular}

these 2 variables per capita in the periods of 1979-1980 (correlation coefficient: $0.365, P<0.01$ ) and also 19801981 (correlation coefficient: $0.369, P<0.01)(21)$.

\section{Maternal Diet}

A study in 2001-2009 was conducted to evaluate the effect of mineral intake. A total of 175 women, with a preference for baby girls, were offered strict diet advice for limitation of sodium and potassium intake and an emphasis on calcium and magnesium intake beside 400-600 mg magnesium + 500-700 mg calcium + 5-7.5 $\mu \mathrm{g}$ vitamin $\mathrm{D}$ supplementation in a normal feeding pattern. They were advised to start the diet 9 weeks before the planned pregnancy and continue it until a positive pregnancy test is occurred. Compliance with the diet was assessed through blood analysis. Seventy-three of the born babies were girl. The sex was significantly dependent on the diet $(P=0.0001)(22)$.

In 2008, Mathew et al studied 740 British pregnant women who were unaware of the sex of their fetus. They were asked to fulfill a retrospective report of the usual diet in the year prior to conception in their first prenatal visit (approximately 14 weeks gestation) and in the 28 weeks gestation. The dietary pattern was categorized into 2 groups: factor 1 was high in vitamin $\mathrm{C}$, folate, a range of minerals, protein, and fat, and factor 2 consisted of a high level of vitamin B12. Factor 1 was associated with a male sex (Wald $\chi^{2}=6.74, P=0.00095$ ) while the latter one was not (Wald $\chi^{2}=0.22, P=0.64$ ). The first factor scores were strongly correlated with energy intake $(r=0.87, P=0.001)$. The odds ratio for having a male infant was 1.5 times for women in the highest tertile of energy intake compared with those in the lowest tertile (95\% CI [1.1, 2.2]). There were no significant associations between anthropometric measurements and the child's sex. After analyzing 133 foods from the food frequency questionnaire, only cereal was strongly associated with a male $\operatorname{sex}\left(\chi^{2}=8.2, P=0.004\right)$. Moreover, sodium and potassium were consumed predominantly by mothers who delivered boys $(P=0.003$, $P=0.046$, respectively) (23).

\section{Discussion}

Regarding the topic of this article, it can be pointed out that there are functional and ethical limitations to design studies with high power methods such as the trials; therefore, most of the researchers have tried to test the hypotheses through observing national samples in different socioeconomic conditions. Wars and famines are one of the best conditions for poor nutritional status observations. The studies of the Chinese Great Leap Forward Famine in 1959-1961 and the French Revolutionary Wars against Germany in 1787-1802 showed a decline in the sex ratio at birth $(9,13)$, although in studies on the Dutch famine of 1944-1945 and food shortage in Ethiopia in 2000, the sex ratio was not affected by war and famine $(10,14,16)$. These contrary results could be explained by the length of the years with famine in these countries. As the V-shaped pattern of the sex ratio in Chinese famine showed, a famine probably took some time to affect the sex ratio (9).

As it is believed, famine studies cannot differentiate between the 2 mechanisms of the malnutrition effect on sex ratio, namely, selective implementation hypothesis (7) or selective fetal loss hypothesis (6). Song showed a decline in the sex ratio in women who spent their first trimester of pregnancy in famine (9); the results were supported by a study on Italian women in a society with no famine or war (19). In both studies, the sex ratio was lower in mothers with lower weight in the first trimester of pregnancy. As a result, it could be concluded that the first trimester of pregnancy was an important period for the effect of nutrition on the sex ratio. The low rate of sex ratio in mothers with weight gain more than $15 \mathrm{~kg}$ during pregnancy showed the impact of poor maternal metabolic conditions on the sex ratio (19).

It should be considered that famine and malnutrition could also affect the fetal loss during pregnancy (24). Moreover, it is a fact that the male fetus is more vulnerable than a female one (25). Famine or war could also affect the sex ratio through increasing mortality. Moreover, it should be noted that famine and malnutrition could also have an effect on the fetal loss during pregnancy (24). In addition, famine and war were found to have an impact on congenital anomalies, reduced rate of pregnancy, and increased mortality in population (26) all of which influenced the sex ratio as well.

Some studies have mentioned anthropometric measurements as a maternal nutritional status indicator. Gibson and Mace, for example, displayed a significant relationship between a BMI under $18.5 \mathrm{~kg} / \mathrm{m}^{2}$ and the child's sex $(17,18)$. However, Stein did not find similar results in this respect (16). It should be noted that, although all the 3 studies were conducted with similar protocols in Ethiopia, the population in Gibson study was not representative of the Ethiopian women since the prevalence of malnutrition was $20 \%$ lower than the 
general and the sex ratio was 88:100 versus 104.5:100 (16).

Furthermore, Mace believed that these contrary results with Stein's were due to the analyses in rural/urban subgroups because rural women were more involved in shortage and that acute malnutrition was more severe among them (18).

Although Denny found no relationship between the maternal BMI and the sex of the child in British mothers (11), the results were analyzed in BMI subgroups and it was found that they were not accurate enough.

Although the waist circumference was significantly related with the sex ratio, Manning et al reported that it was a marker of the testosterone level in females (20). Unlike the default assumption, obesity was associated with decreased levels of total and free testosterone and of SHBG (sex hormone binding globulin) (27) so the waist circumference was an anthropometric marker rather than a hormonal marker. However, Svartberg et al also indicated that the waist circumference could be a predictor for endogenous testosterone levels (28). Besides, this marker was tested in only 102 women and was not used in a larger population.

In the above-mentioned studies, the duration between anthropometric measurements and pregnancy could have caused a bias. There are doubts whether the anthropometric measurements were constant within these years and actually represented the maternal nutritional status around their pregnancy. For instance, cultural background might have resulted in more weight gain in the postpartum period (18).

Mathew et al (23) reported that about $56 \%$ of the women in the highest tertile of pre-conception energy intake delivered boys as compared with $45 \%$ of those in the lowest tertile. This is in line with a report by Williams and Gloster (21). However, according to the dietary reports of women, recall bias was also probable. Moreover, Young et al argued about the results of this study and showed that a multiple testing false positive occurred. They explained the results as a chance (29).

Similarly, Noorlander et al claimed that a diet high in sodium and potassium and low in magnesium and calcium could induce a female fetus (22). This report is was conformity with the Mathew's findings. They designed a prospective study to better control the conditions and to reduce the recall bias.

There are numerous reports on the effect of maternal mineral intake on the offspring's sex in the literature from the past. For instance, Herbst for the first time showed that potassium concentration in seawater could change the sex ratio from 0.1 to 10 (30). Later studies showed that a high intake of $\mathrm{K}^{+}$and $\mathrm{Na}^{+}$and a low intake of $\mathrm{Ca}^{++}$and $\mathrm{Mg}^{++}$ increased the sex ratio in sows and rats $(31,32)$. Some studies tested these hypotheses before Mathew et al (23) and Noorlander et al (22) and reported similar findings, but as their electronic full texts were not available, the researchers of this study decided to exclude them from the review $(33,34)$. Nonetheless, there were not enough articles in this regard to prove the hypothesis.

\section{Conclusions}

It seems that the nutritional status may not affect the sex ratio at birth unless in malnutrition. Even in severe acute malnutrition, it took time for the effects to appear. More studies in different populations and conditions with accurate methods are needed to make a valid and definite conclusion in this regard. There were not enough publications regarding the effect of the maternal nutrition on the sex ratio in the literature, and thus more researches are warranted.

\section{Conflict of Interests}

Authors declare that they have no conflict of interests.

\section{Ethical Issues}

Not applicable.

\section{Financial Support}

This work was supported by the Vice chancellor of Research of Mashhad University of Medical Sciences.

\section{Acknowledgements}

The authors thank Dr. Taghipour for his advice on implementation of this research.

\section{References}

1. Kaiser LL, Campbell CG. Practice paper of the Academy of Nutrition and Dietetics abstract: nutrition and lifestyle for a healthy pregnancy outcome. J Acad Nutr Diet. 2014;114(9):1447. doi:10.1016/j.jand.2014.07.001

2. Grieger JA, Clifton VL. A review of the impact of dietary intakes in human pregnancy on infant birthweight. Nutrients. 2014;7(1):153-178. doi:10.3390/nu7010153

3. Pitkin RM. Nutritional influences during pregnancy. Med Clin North Am. 1977;61(1):3-15. doi:10.1016/S00257125(16)31346-3

4. Mirghani HM, Hamud OA. The effect of maternal diet restriction on pregnancy outcome. Am J Perinatol. 2006;23(1):21-24. doi:10.1055/s-2005-923435

5. Hossain AM, Barik S, Rizk B, Thorneycroft IH. Preconceptional sex selection: past, present, and future. Arch Androl. 1998;40(1):3-14. doi:10.3109/01485019808987923

6. Myers JH. Sex ratio adjustment under food stress: maximization of quality or numbers of offspring? Am Nat. 1978;112(984):381-388.

7. Trivers RL, Willard DE. Natural selection of parental ability to vary the sex ratio of offspring. Science. 1973;179(4068):90-92.

8. Song S. Malnutrition, sex ratio, and selection: a study based on the great leap forward famine. Hum Nat. 2014;25(4):580595. doi:10.1007/s12110-014-9208-1

9. Song S. Does famine influence sex ratio at birth? Evidence from the 1959-1961 Great Leap Forward Famine in China. Proc Biol Sci. 2012;279(1739):2883-2890. doi:10.1098/ rspb.2012.0320 
10. Cramer JS, Lumey LH. Maternal preconception diet and the sex ratio. Hum Biol. 2010;82(1):103-107. doi:10.3378/027.082.0106

11. Denny K. Big and tall parents do not have more sons. J Theor Biol. 2008;250(4):752-753. doi:10.1016/j.jtbi.2007.11.004

12. Saalfeld D. Wandlungen der bäuerlichen Konsumgewohnheiten vom Mittelalter zur Neuzeit. Deutschland: Essen und Trinken; 1987.

13. Kemkes A. Secondary sex ratio variation during stressful times: the impact of the French revolutionary wars on a German parish (1787-1802). Am J Hum Biol. 2006;18(6):806-821. doi:10.1002/ajhb.20562

14. Stein AD, Zybert PA, Lumey LH. Acute undernutrition is not associated with excess of females at birth in humans: the Dutch hunger winter. Proc Biol Sci. 2004;271 Suppl 4:S138-141. doi:10.1098/rsbl.2003.0123

15. USAID-FEWS NET. Ethiopia food security update. http:// fews.net/east-africa/ethiopia/food-security-outlookupdate/july-2000.

16. Stein AD, Barnett PG, Sellen DW. Maternal undernutrition and the sex ratio at birth in Ethiopia: evidence from a national sample. Proc Biol Sci. 2004;271 Suppl 3:S37-39. doi:10.1098/rsbl.2003.0086

17. Gibson MA, Mace R. Strong mothers bear more sons in rural Ethiopia. Proc Biol Sci. 2003;270 Suppl 1:S108-109. doi:10.1098/rsbl.2003.0031

18. 18. Mace R, Eardley J. Maternal nutrition and sex ratio at birth in Ethiopia. In: Alvard MS, ed. Socioeconomic Aspects of Human Behavioral Ecology. Emerald Group Publishing Limited; 2004: ;295-306. doi:10.1016/s01901281(04)23012-8.

19. Cagnacci A, Renzi A, Arangino S, Alessandrini C, Volpe A. Influences of maternal weight on the secondary sex ratio of human offspring. Hum Reprod. 2004;19(2):442-444. doi:10.1093/humrep/deh071

20. Manning JT, Anderton R, Washington SM. Women's waists and the sex ratio of their progeny: evolutionary aspects of the ideal female body shape. J Hum Evol. 1996;31(1):41-47. doi:10.1006/jhev.1996.0047

21. Williams RJ, Gloster SP. Human sex ratio as it relates to caloric availability. Soc Biol. 1992;39(3-4):285-291. doi:10. 1080/19485565.1992.9988823

22. Noorlander AM, Geraedts JP, Melissen JB. Female gender pre-selection by maternal diet in combination with timing of sexual intercourse--a prospective study. Reprod Biomed Online. 2010;21(6):794-802. doi:10.1016/j. rbmo.2010.08.002

23. Mathews F, Johnson PJ, Neil A. You are what your mother eats: evidence for maternal preconception diet influencing foetal sex in humans. Proc Biol Sci. 2008;275(1643):16611668. doi:10.1098/rspb.2008.0105

24. Cai Y, Feng W. Famine, social disruption, and involuntary fetal loss: evidence from Chinese survey data. Demography. 2005;42(2):301-322. doi:10.1353/dem.2005.0010

25. Kraemer S. The fragile male. BMJ. 2000;321(7276):16091612.

26. Jongbloet PH, Zielhuis GA, Groenewoud HM, Pasker-De Jong PC. The secular trends in male:female ratio at birth in postwar industrialized countries. Environ Health Perspect. 2001;109(7):749-752. doi:10.1289/ehp.01109749

27. Derby CA, Zilber S, Brambilla D, Morales KH, McKinlay JB. Body mass index, waist circumference and waist to hip ratio and change in sex steroid hormones: the Massachusetts Male Ageing Study. Clin Endocrinol (Oxf). 2006;65(1):125131. doi:10.1111/j.1365-2265.2006.02560.x

28. Svartberg J, von Muhlen D, Sundsfjord J, Jorde R. Waist circumference and testosteronelevelsin communitydwelling men. The Tromso study. Eur J Epidemiol. 2004;19(7):657663. doi:10.1023/B:EJEP.0000036809.30558.8f

29. Young SS, Bang H, Oktay K. Cereal-induced gender selection? Most likely a multiple testing false positive. Proc Biol Sci. 2009;276(1660):1211-1212; discussion 1213-1214. doi:10.1098/rspb.2008.1405

30. Herbst C. Untersuchungen zur Bestimmung des Geschlechts. Dev Genes Evol. 1935;132(4):576-599. doi:10.1007/bf00574188

31. Bolet G, Gueguen L, Dando P, Ollivier L. [Influence of mineral diet of the sow on the sex ratio of the newborn]. Reprod Nutr Dev. 1982;22(6):1073-1081.

32. Vahidi AR, Sheikhha MH. Comparing the effects of sodium and potassium diet with calcium and magnesium diet on sex ratio of rats' offspring. Pak J Nutr. 2007;6(1):44-48. doi:10.3923/pjn.2007.44.48

33. Papa F, Henrion R, Breart G. [Preconceptional selection of sex using the ionic method. Dietary regime. Results of a 2 years' prospective clinical study]. J Gynecol Obstet Biol Reprod (Paris). 1983;12(4):415-422.

34. Ganj Lou J, Danesh AR, Hajzadeh MR, Torabizadeh A, Mazloom SR, Nejat Shokouhi A. Study of the effect of sodium, potassium, calcium and magnesium lons of women's diet on the preconceptional choice of the baby's sex. J Sabzevar Univ Med Sci. 2003;9(4):6-12.

(C) 2018 The Author (s); This is an open-access article distributed under the terms of the Creative Commons Attribution License (http://creativecommons.org/licenses/by/4.0), which permits unrestricted use, distribution, and reproduction in any medium, provided the original work is properly cited. 